ISSN 1392-3196 / e-ISSN 2335-8947

Zemdirbyste-Agriculture, vol. 100, No. 2 (2013), p. 205-212

DOI $10.13080 /$ z-a.2013.100.027

\title{
A review of research studies into pesticide residues in food in Lithuania
}

\author{
Julijonas PETRAITIS ${ }^{1}$, Inga JARMALAITE ${ }^{1}$, Virginijus VAIČIŪNAS ${ }^{1}$, \\ Remigijus UŠČINAS ${ }^{2}$, Giedre JANKOVSKIENE ${ }^{3}$ \\ ${ }^{1}$ National Food and Veterinary Risk Assessment Institute \\ J. Kairiūkščio 10, Vilnius, Lithuania \\ E-mail: julius.petraitis@zmail.lt \\ ${ }^{2}$ Joint stock company "Labtarna" \\ Kauno 1A, Vilnius, Lithuania \\ ${ }^{3}$ National Public Health Surveillance Laboratory \\ Žolyno 36, Vilnius, Lithuania
}

\begin{abstract}
The current paper presents the evolution of pesticide research in Lithuania during the period 1970-2010. Analyses were based on single residue methods until 1993. Most of the products were of domestic origin and it was known exactly which pesticides had been used, therefore it was possible to obtain the necessary information about the contamination by single residue methods. Simple and inexpensive methods were used, which allowed five laboratories to analyze 3-5 thousand samples per year. In 1972, a high level of contamination (up to 8.1\%) in food of animal origin was determined. This resulted from environmental pollution and feed contamination with organochlorine pesticides. Later this contamination decreased, and animal products no longer posed a major pollution problem. The contamination of food of plant origin was at level 1-3\%. A significant increase in imports and the lack of information on pesticides used made the single residue methods unsuitable to ensure effective contamination control. The multiresidue methods were developed. Implementation of multiresidue methods enables a laboratory to determine up to 300 pesticides per sample. A total of 4593 samples of food of plant origin were analysed by multiresidue methods, pesticide residues were determined in 1428 samples ( $31 \%)$, exceedances of maximum residue levels (MRLs) were determined in 120 samples $(2.6 \%)$. This data are comparable with the pesticide monitoring results obtained in other European countries.
\end{abstract}

Key words: food, multiresidue method, pesticide, pesticide residues, single residue method.

\section{Introduction}

Various materials as pesticides have been used for many years to control pests. The first synthetic organic pesticides were organochlorine compounds, such as dichlorodiphenyltrichloroethane (DDT). It was cheap to produce, very toxic to insects, and much less toxic to mammals. From 1950 to 1970 , more than 20 thousand tonnes of DDT were used annually over large areas of the Soviet Union. As a result, dangerously high residue levels were found in both food and human tissue (DDT Factsheet, 1998). In 1970, DDT was banned for use in agriculture, but it remained a widespread and persistent environmental contaminant. Long after banning, DDT together with its breakdown products remained dangerous to human health and the environment and even after 20 30 years their residues were detected in food (Pesticide Residues..., 1996). DDT has not been officially used in Lithuania since 1970; however, organochlorine pesticides were used to protect cotton, wheat, and to fight with malaria in the southern regions (DDT Factsheet, 1998). According to Food safety issue (Pesticide Residues..., 1996), high contamination of cereals with $1.2 \mathrm{mg} \mathrm{kg}^{-1}$
2,4'-DDT and $1.3 \mathrm{mg} \mathrm{kg}^{-1} 4,4^{\prime}$-DDT was determined in wheat from the Soviet Union.

The control of the pesticide residues in Lithuania covers a forty-year period. The information on the pesticide residues analysis was presented in the conferences (Uščinas et al., 1999; Petraitis et al., 2001; 2007; 2009; 2011; Jarmalaitè et al., 2003; Vaičiūnas et al., 2011; Golubevas et al., 2012). However, there was no published scientific information on pesticide residue analysis in Lithuania during this period. Therefore the objective of this paper was to summarise the experience of Lithuanian chemists in pesticide residue analysis.

\section{Results and discussion}

The official food control was established in the Soviet Union and in Lithuania in 1970. Four USSR governmental institutes were working continuously on developing methods for determination of pesticide residues and toxicity evaluation. They developed single residue methods, and established maximum 
residue limits for the pesticides used in the USSR. Control was conducted by hygiene laboratories of Ministry of Health. The main attention was paid to organochlorine pesticides: DDT and metabolites, kelthane (dicofol), hexachlorobenzene, isomers of 1,2,3,4,5,6-hexachlorcyclohehane, polychlorpinene, heptachlor over the 1970-1975 period. Other important groups were carbamates, organic mercury compounds, and copper residues. During the 1970-1971 period, over 3000 environment (surface and drinking water from wells) and food samples were analysed. High levels of pesticide residues were determined in food of animal origin. The number of food and water samples increased to 4000 (3607 food samples +398 water samples) in
1972 and to 6000 samples in 1973-1976. In later years, the number of samples decreased to 3000-4000. The number of pesticides analysed was not high, up to 30 compounds mainly organochlorine pesticides, copper and mercury residues. High contamination levels of food of animal origin were determined mostly in fish (22\%) and eggs (4.4\%). A possible reason for such a high level of contaminated products was environmental pollution and import of wheat for animal feed production from the regions where DDT was used. There were exceedances of MRLs in $1-1.5 \%$ of samples of milk and milk products and $0-2.3 \%$ in the samples of food of plant origin. More detailed information is presented in Table 1.

Table 1. Results of food analyses in 1972, 1976, 1980, 1983, 1986 and 1993

\begin{tabular}{|c|c|c|c|c|c|c|c|c|c|}
\hline Foodstuff & $\begin{array}{c}\text { No. of } \\
\text { samples }\end{array}$ & $\begin{array}{c}\text { Above the } \\
\text { MRL }\end{array}$ & $\%$ & $\begin{array}{c}\text { No. of } \\
\text { samples }\end{array}$ & $\begin{array}{c}\text { Above the } \\
\text { MRL }\end{array}$ & $\%$ & $\begin{array}{l}\text { No. of } \\
\text { samples }\end{array}$ & $\begin{array}{c}\text { Above the } \\
\text { MRL }\end{array}$ & $\%$ \\
\hline & \multicolumn{3}{|c|}{1972} & \multicolumn{3}{|c|}{1976} & \multicolumn{3}{|c|}{1980} \\
\hline Fruits and vegetables & 1184 & 27 & 2.3 & 1133 & 5 & 0.44 & 796 & 9 & 1.3 \\
\hline $\begin{array}{c}\text { Cereals and other food } \\
\text { of plant origin }\end{array}$ & 279 & 3 & 1.1 & 295 & 0 & 0 & 223 & 0 & 0 \\
\hline $\begin{array}{l}\text { Milk and milk } \\
\text { products }\end{array}$ & 1500 & 15 & 1.0 & 2195 & 18 & 0.8 & 1510 & 22 & 1.5 \\
\hline $\begin{array}{l}\text { Meat, fish and other } \\
\text { food of animal origin }\end{array}$ & 644 & 52 & 8.1 & 855 & 32 & 3.7 & 718 & 12 & 1.7 \\
\hline Total food & 3607 & 97 & 2.7 & 4478 & 55 & 1.1 & 3247 & 43 & 1.3 \\
\hline \multirow[t]{2}{*}{ Water } & 398 & 5 & 1.3 & 518 & 0 & 0 & 332 & 3 & 0.9 \\
\hline & \multicolumn{3}{|c|}{1983} & \multicolumn{3}{|c|}{1986} & \multicolumn{3}{|c|}{1993} \\
\hline Fruits and vegetables & 918 & 13 & 1.4 & 1733 & 37 & 2.1 & 613 & 10 & 1.6 \\
\hline $\begin{array}{l}\text { Cereals, oil and other } \\
\text { food of plant origin }\end{array}$ & 195 & 7 & 3.6 & 401 & 0 & 0 & 233 & 1 & 0.4 \\
\hline $\begin{array}{l}\text { Milk and milk } \\
\text { products }\end{array}$ & 1226 & 21 & 1.7 & 691 & 2 & 0.3 & 387 & 2 & 0.5 \\
\hline $\begin{array}{l}\text { Meat, fish and other } \\
\text { food of animal origin }\end{array}$ & 691 & 5 & 0.7 & 701 & 0 & 0 & 277 & 0 & 0 \\
\hline Total food & 3016 & 46 & 1.5 & 3526 & 39 & 1.1 & 1510 & 13 & 0.86 \\
\hline Water & 222 & 2 & 0.9 & 247 & 0 & 0 & 187 & 2 & 1.1 \\
\hline
\end{tabular}

MRL - maximum residue level

Contamination of food of animal origin considerably decreased from 1980 as a result of decreasing environmental pollution and less contaminated feeds by organochlorine pesticides. No exceedance of MRLs was determined in meat, eggs, and fish since 1986. More attention was paid to analysis of food of plant origin and the number of these samples exceeded 2000 per year. Frequency of MRL exceedances was about $1.5-2.0 \%$. The results of analyses of pesticide residues in food in 1983, 1986 and 1993 are presented in Table 1.

Methods for determination of carbamates, organophosphosphorus and other pesticides were implemented in this period to analyse food of plant origin. More than 600 single residue methods were developed for determination of up 100 pesticide residues in different kind of plant matrixes until 1985. The pesticide residues control system was implemented in the Soviet Union for evaluation and statistical analysis of food contamination. This system was well organised for domestic products and was suitable for planned soviet economy. All of the necessary information on what pesticides were used for a particular commodity was provided with the sampling documents making it easier for the laboratories to select the single residue methods. After the year 1990, the main system of agriculture in USSR - collective farms collapsed, but the same pesticides were used for another few years in agriculture. Lithuanian food control system collaborated with the former USSR pesticide residue control system centre in the Ukraine, until 1992. However, this system was not effective to control contamination of imported food of plant origin.

Lithuanian farmers started to use new pesticides purchased from western companies. Most of the activities were aimed to evaluate possible contamination of plant origin domestic products with pesticide residues during field test necessary for registration of a new pesticide formulation in Lithuania. However, the control of imported products of plant origin by single residue methods was ineffective.

Environmental pollution with organochlorine pesticides stipulated accumulation of these pesticide residues in fish, animal and human tissues. Analyses of pesticide residues accumulated in human fat were conducted in 1998. Aldrin, dieldrin, 2,4'-DDE (dichlorodiphenyldichloroethylene), 4,4'-DDE, 2,4'DDD (dichlorodiphenyldichloroethane), 4,4'-DDD, $\alpha$ and $\beta$-endosulfanes, endrine, $\alpha$-hexachlorcyclohexane $(\mathrm{HCH})$, lindane, heptachlor, 2,4'-DDT, 4,4'-DDT 
residues were analysed in 19 samples. The residues of 4,4'-DDE, $\alpha-\mathrm{HCH}$, lindane, were determined in 15 (78\%) samples (Uščinas et al., 1999). Similar pesticides were determined in human fat by researchers of other countries. Organochlorine pesticide residues were found in $63.2 \%$ of samples in Spain (Molina et al., 2005).

The total level of contamination of food of animal origin was decreasing over the years and since 1994 only a few times MRLs were exceeded in domestic products of animal origin. However, the measurable residues in some commodities were still found in food in Lithuania and other European Union (EU) countries. According to the EU-coordinated programme, 473 butter samples and 559 egg samples were analysed during the calendar year 2009 . The measurable residues were found in $19.9 \%$ of the butter samples. Alpha-HCH and endosulfan exceeded the MRL in two butter samples. The most frequently found residues in butter were hexachlorbenzene, DDT, methohychlor, dieldrin, $\mathrm{HCH}$ and endosulfan. The measurable residues were found in $4.5 \%$ of egg samples and in one sample DDT exceeded the MRL, other residues found below the MRL were hexachlorobenzene, lindane, dieldrin, chlordane, chlorpyrifos and cypermetrin (Scientific Report..., 2011). Sixteen butter and 12 chicken egg samples were analysed in Lithuania according to this programme; two butter samples contained $\alpha$-HCH below the MRL. During the calendar year 2010, no pesticide residues were found in 10 milk and 8 meat samples, analysed in Lithuania. Although most of these pesticides are no longer used in the EU and in most third countries, they are still found in food because of their persistence and tendency to accumulate in the food chain.

A new step to control the pesticide residues in food of plant origin started in 1998. The multiresidue method by capillary gas chromatography (GC) with electron capture and nitrogen phosphorus detectors has been developed in the laboratory of the National Nutrition Centre. Ethyl acetate was chosen as the extraction solvent before the clean-up procedure on gel permeation chromatography column filled with "Bio Beads S-X3" sorbent, while ethyl acetate/cyclohexane 1:1 was used as the mobile phase. This method included 55 pesticides and was used for import control mainly. Thirty samples of imported fruits and vegetables (oranges, mandarins, lemons, apples celery, tomatoes, and others) and wine were analysed in 1999. Pesticide residues were determined in 23 samples; however, most of the results had not been evaluated, as there were no national MRLs for these products. Investigations were expanded in 2000. A total of 200 samples were analysed, of which 114 were of domestic origin. The highest contamination was determined in imported fruits, especially citrus fruit and grapes.

The reorganisation of food control system took place in 2000. State Food and Veterinary Service was established, whose responsibilities included pesticide residue analyses and preparation of a control system. The pesticide residue control in food of plant origin was renewed in 2001 and 221 samples were analysed for 46 pesticide residues. Analysis of domestic samples indicated low contamination of domestic products. Pesticide residues were determined in 6 samples out of $55(11 \%)$ and none exceeded the MRL. The imported samples were contaminated in higher degree, pesticide residues were determined in 49 samples out of 166
(29.5\%). MRLs were exceeded in 5 samples out of 166 $(3.0 \%)$ - cucumbers, head cabbages, apples, peppers and raisins.

Acetone and ethyl acetate/cyclohexane mixture $(1+1)$ were used as extraction solvents before gel permeation chromatography clean-up procedure with the mobile phase ethyl acetate/cyclohexane $(1+1)$ and additional clean-up with mini-silica column following GC and detection with the electron capture and nitrogen and phosphorus detector, mass spectrometry (MS) detectors. This system allowed determination of 130 pesticide residues in 2006. The new analytical systems: GC/MS and liquid chromatography-tandem mass spectrometry (LC-MS/MS) were implemented in 2007. This allowed the pesticide residue scope to be increased up to 230 in 2008. The QuEChERS (quick, easy, cheap, effective, rugged, safe) is the acronym for a highly beneficial analytical approach that vastly simplifies the analysis of multiple pesticide residues in fruit, vegetables, cereals and processed products thereof. QuEChERS sample preparation approach entailing solvent extraction with acetonitrile, partitioning with magnesium sulphate alone or in combination with other salts followed by clean up using solid-phase extraction. The combination of these extractions - clean-up methods with GC/MS and LC-MS/ MS analysis allowed the number of pesticides that can be determined in one sample to be increased up to 274 in 2009 , and up to 300 in 2010 and the limits of determination for many residues to be decreased to $0.002-0.01 \mathrm{mg} \mathrm{kg}^{-1}$. However, it is not possible to analyse all of the pesticide residues by multiresidue methods, laboratory has to apply single residue methods for the determination of dithiocarbamates, chlormequat, and glyphosate. The new methods allow determination of pesticide residues with the concentrations below $0.01 \mathrm{mg} \mathrm{kg}^{-1}$.

The monitoring programme of pesticide residues in food products according to EU requirements was prepared and implemented in 2002. More than 60 different commodities both imported and domestic were included in the programme. The programme covers 69 pesticides including some isomers. The contamination of domestic samples was low - 3 samples out of $65(4.6 \%)$ were with residues below the MRL. The number of samples containing pesticide residues was higher in imported products - 109 samples out of $350(31.1 \%)$. MRLs were exceeded in 6 samples out of $350(1.7 \%)$. Percentage of samples obtained by the EU monitoring programme with detectable residues was $37 \%$ and frequency of MRLs exceedances reached 5.1\% (Monitoring..., 2004).

Similar results were obtained in 2003, except an increase of exceedances of MRLs to $2.6 \%$, depending on the contaminated tea import from China. Exceedances of MRLs were determined in grapefruits -2 samples, oranges, carrots and peppers -4 samples. The main residue determined in peppers was endosulfan with quantity between $0.2-0.5 \mathrm{mg} \mathrm{kg}^{-1}$. The European MRLs increased from $0.2 \mathrm{mg} \mathrm{kg}^{-1}$ to $0.5 \mathrm{mg} \mathrm{kg}^{-1}$, and there were no exceedances of endosulfan residues later. Percentage of samples with detectable residues obtained by the EU monitoring programme was $37 \%$ and frequency of MRLs exceedances reached 5.5\% (Monitoring..., 2005).

The level of samples with detectable residues $21.8 \%$ and exeedances of MRLs $1.7 \%$ was lower in 2004, a similar situation was in 2005 samples with detectable residues $25.9 \%$ and exeedances of MRLs $1.5 \%$. Since 
2004, the data obtained by the national pesticide monitoring programme have been included in the EU monitoring results data base. Percentage of samples with detectable residues obtained by the EU monitoring programme in 2004 and 2005 was $39.7 \%$ and $41.0 \%$ and frequency of MRLs exceedances was $4.7 \%$ and $4.7 \%$, respectively (Monitoring..., 2006; 2007).

The level of samples with detectable residues $28.0 \%$ and exeedances of MRLs had reached $2.3 \%$ in $2006,30.1 \%$ and $4.6 \%$ in 2007, $21.2 \%$ and $2.6 \%$ in 2008 . Percentage of samples with detectable residues obtained by the EU monitoring programme in 2006, 2007 and 2008 was 42.0, 45.0 and $35.7 \%$ and frequency of MRLs exceedances was 4.4, 4.2 and $3.5 \%$, respectively (Monitoring..., 2007; 2008; Annual Report..., 2009; 2010). According to USA monitoring programme, percentage of samples with detectable residues was 28.5, 39.7 and $34.9 \%$ in 2006, 2007 and 2008 for domestic products and 28.1, 31.0, and $23.0 \%$ for imported products. Pesticide levels exceeding established MRLs in 2006, 2007 and 2008 were 1.6, 2.3, and $0.9 \%$, in domestic products and 5.4, 4.7, and $4.7 \%$ in imported samples (Pesticide Monitoring Program..., 2006; 2007; 2008). Brazilian monitoring programme team have reported monitoring data between 2001 and 2010. They found pesticide residues in $48.3 \%$ of the samples and less than $3 \%$ of the samples that had residue levels above the MRL (Jardim, Caldas, 2012). China's researchers found selected pesticide residues in $37.7 \%$ of the samples
(Chen et al., 2011). The difference in the results depends on different factors, commodity selected, method of sampling, pesticide residue searched, method of analysis, country of origin. The selective evaluation of pesticide residues in fruits and vegetables from South America was done by Nordic project in 2007. High levels of pesticide residue were determined. $72 \%$ of samples contained pesticide residues at or MRL and $8.4 \%$ of samples contained pesticide residue above the MRL (Hjorth et al., 2011). In some cases thiabendazole and imazalil were determined; they are used as fungicides to protect citrus fruits and bananas during transportation.

Implementation of modern analytical methods has made it possible to increase the number of pesticides sought per sample to 300 and to decrease the limit of determination to $0.002 \mathrm{mg} \mathrm{kg}^{-1}$. The level of samples with detectable residues increased to $44.6 \%$ and exceedances of MRLs to $3.4 \%$ in 2009 and to $59.8 \%$ of detectable residues with MRL exceedances to $4.2 \%$ in 2010. Another reason for increased exceedances of MRLs was that the higher proportion of fruit samples was imported from the third countries. These commodities are usually more contaminated with pesticide residues compared to the products from the EU countries. Percentage of samples with detectable residues obtained by the EU monitoring programme was $37.4 \%$ and frequency of MRLs exceedances fell down to $2.6 \%$ in 2009 (Scientific Report..., 2011). Results of pesticide residues analyses in Lithuania from 1999 to 2010 are presented in Table 2.

Table 2. Results of pesticide residues analyses in 1999-2010

\begin{tabular}{|c|c|c|c|c|c|c|c|c|c|c|}
\hline \multirow[t]{2}{*}{ Year } & \multirow{2}{*}{$\begin{array}{c}\text { Samples } \\
\text { analysed }\end{array}$} & \multicolumn{2}{|c|}{$\begin{array}{l}\text { With residues } \\
\text { below MRL }\end{array}$} & \multicolumn{2}{|c|}{$\begin{array}{c}\text { With residues above } \\
\text { MRL }\end{array}$} & \multicolumn{2}{|c|}{ Pesticide residues } & \multicolumn{3}{|c|}{ Samples origin $* * * *$} \\
\hline & & No. & $\%$ & No. & $\%$ & Sought & Found & Dom & $\mathrm{EU}$ & Third \\
\hline 1 & 2 & 3 & 4 & 5 & 6 & 7 & 8 & 9 & 10 & 11 \\
\hline 1999 total & 30 & 23 & 76.7 & 0 & 0 & 55 & 26 & 0 & 17 & 13 \\
\hline Fruits* & 21 & 18 & 85.7 & 0 & 0 & 55 & 22 & 0 & 10 & 11 \\
\hline Vegetables** & 4 & 3 & 75 & 0 & 0 & 55 & 21 & 0 & 4 & 0 \\
\hline Wine & 5 & 2 & 40 & 0 & 0 & 55 & 2 & 0 & 3 & 2 \\
\hline 2000 total & 200 & 57 & 28.5 & 3 & 1.5 & 55 & 22 & 114 & 48 & 38 \\
\hline Fruits & 53 & 26 & 49.1 & 3 & 5.7 & 55 & 16 & 10 & 26 & 17 \\
\hline Vegetables & 51 & 14 & 27.5 & 0 & 0 & 55 & 11 & 29 & 10 & 12 \\
\hline Cereals & 75 & 9 & 12.0 & 0 & 0 & 55 & 4 & 75 & 0 & 0 \\
\hline Wine & 21 & 8 & 38.1 & 0 & 0 & 55 & 3 & 0 & 12 & 9 \\
\hline 2001 total & 221 & 50 & 22.6 & 5 & 2.6 & 46 & 21 & 55 & 102 & 64 \\
\hline Fruits & 91 & 22 & 24.2 & 2 & 2.2 & 46 & 15 & 9 & 33 & 49 \\
\hline Vegetables & 119 & 28 & 23.5 & 3 & 2.6 & 46 & 11 & 46 & 62 & 11 \\
\hline Others*** & 11 & 0 & 0 & 0 & 0 & 46 & 0 & 0 & 7 & 4 \\
\hline 2002 total & 415 & 112 & 27.0 & 6 & 1.5 & 69 & 24 & 65 & 234 & 116 \\
\hline Fruits & 179 & 71 & 39.7 & 3 & 1.7 & 69 & 19 & 14 & 93 & 72 \\
\hline Vegetables & 206 & 40 & 19.4 & 3 & 1.5 & 69 & 12 & 42 & 139 & 25 \\
\hline Cereals & 28 & 1 & 3.6 & 0 & 0 & 69 & 1 & 9 & 1 & 18 \\
\hline Others & 2 & 0 & 0 & 0 & 0 & 69 & 0 & 0 & 1 & 1 \\
\hline 2003 total & 495 & 152 & 30.7 & 13 & 2.6 & 96 & 32 & 78 & 235 & 182 \\
\hline Fruits & 146 & 64 & 43.8 & 3 & 2.1 & 96 & 25 & 11 & 63 & 72 \\
\hline Vegetables & 242 & 85 & 35.1 & 10 & 3.9 & 96 & 15 & 53 & 147 & 42 \\
\hline Cereals & 82 & 3 & 3.6 & 0 & 0 & 96 & 2 & 12 & 6 & 64 \\
\hline Others & 25 & 0 & 0 & 0 & 0 & 96 & 0 & 2 & 19 & 4 \\
\hline 2004 total & 468 & 102 & 21.8 & 8 & 1.7 & 105 & 28 & 199 & 102 & 167 \\
\hline Fruits & 147 & 70 & 47.6 & 5 & 3.4 & 105 & 23 & 23 & 28 & 86 \\
\hline Vegetables & 236 & 27 & 11.4 & 3 & 1.3 & 105 & 14 & 127 & 61 & 48 \\
\hline Cereals & 68 & 2 & 2.9 & 0 & 0 & 105 & 1 & 43 & 1 & 24 \\
\hline Others & 17 & 3 & 17.6 & 0 & 0 & 105 & 3 & 6 & 2 & 9 \\
\hline Total 1999-2004 & 1829 & 496 & 27.1 & 35 & 1.9 & & & 511 & 738 & 580 \\
\hline
\end{tabular}


Table 2 continued

\begin{tabular}{|c|c|c|c|c|c|c|c|c|c|c|}
\hline 1 & 2 & 3 & 4 & 5 & 6 & 7 & 8 & 9 & 10 & 11 \\
\hline 2005 total & 466 & 114 & 25.9 & 7 & 1.5 & 130 & 40 & 187 & 112 & 167 \\
\hline Fruits & 179 & 91 & 50.8 & 6 & 3.4 & 130 & 33 & 29 & 53 & 97 \\
\hline Vegetables & 237 & 22 & 9.3 & 1 & 0.4 & 130 & 16 & 128 & 56 & 53 \\
\hline Cereals & 37 & 1 & 2.7 & 0 & 0 & 130 & 1 & 30 & 1 & 6 \\
\hline Others & 13 & 0 & 0 & 0 & 0 & 130 & 0 & 0 & 2 & 11 \\
\hline 2006 total & 436 & 122 & 28.0 & 10 & 2.3 & 205 & 39 & 135 & 119 & 182 \\
\hline Fruits & 156 & 83 & 53.2 & 6 & 3.8 & 205 & 27 & 29 & 31 & 96 \\
\hline Vegetables & 210 & 28 & 13.3 & 3 & 1.4 & 205 & 18 & 80 & 69 & 61 \\
\hline Cereals & 49 & 4 & 9.0 & 1 & 2.0 & 205 & 4 & 23 & 8 & 18 \\
\hline Others & 21 & 7 & 26.9 & 0 & 0 & 205 & 6 & 3 & 11 & 7 \\
\hline 2007 total & 504 & 156 & 30.1 & 23 & 4.6 & 223 & 63 & 118 & 154 & 232 \\
\hline Fruits & 205 & 93 & 45.4 & 18 & 8.8 & 223 & 54 & 29 & 53 & 123 \\
\hline Vegetables & 233 & 58 & 24.5 & 5 & 2.1 & 223 & 30 & 63 & 85 & 85 \\
\hline Cereals & 53 & 4 & 7.5 & 0 & 0 & 223 & 4 & 24 & 6 & 23 \\
\hline Others & 13 & 1 & 7.7 & 0 & 0 & 223 & 6 & 2 & 10 & 1 \\
\hline 2008 total & 529 & 112 & 21.2 & 14 & 2.6 & 230 & 52 & 113 & 156 & 260 \\
\hline Fruits & 226 & 88 & 38.9 & 7 & 3.1 & 230 & 37 & 30 & 58 & 138 \\
\hline Vegetables & 224 & 19 & 8.5 & 6 & 2.7 & 230 & 28 & 65 & 83 & 76 \\
\hline Cereals & 54 & 3 & 5.6 & 1 & 1.9 & 230 & 5 & 15 & 6 & 33 \\
\hline Others & 23 & 2 & 4.2 & 0 & 0 & 230 & 4 & 2 & 9 & 12 \\
\hline 2009 total & 446 & 199 & 44.6 & 15 & 3.4 & 325 & 75 & 82 & 144 & 220 \\
\hline Fruits & 265 & 150 & 56.6 & 8 & 3.0 & 274 & 71 & 5 & 51 & 135 \\
\hline Vegetables & 112 & 44 & 39.3 & 6 & 5.4 & 274 & 35 & 18 & 76 & 18 \\
\hline Cereals & 30 & 3 & 14.3 & 1 & 3.3 & 250 & 1 & 17 & 0 & 13 \\
\hline Others & 11 & 0 & 0 & 0 & 0 & 274 & 0 & 0 & 9 & 2 \\
\hline Milk, eggs & 28 & 2 & 7.1 & 0 & 0 & 48 & 1 & 28 & 0 & 0 \\
\hline 2010 total & 383 & 229 & 59.8 & 16 & 4.2 & 349 & 99 & 94 & 124 & 165 \\
\hline Fruits & 213 & 161 & 75.6 & 14 & 6.6 & 302 & 97 & 14 & 58 & 141 \\
\hline Vegetables & 101 & 59 & 58.4 & 1 & 1.0 & 301 & 52 & 39 & 53 & 9 \\
\hline Cereals & 29 & 7 & 24.1 & 0 & 0 & 304 & 14 & 20 & 2 & 7 \\
\hline Others & 22 & 2 & 9.1 & 1 & 4.5 & 301 & 12 & 3 & 11 & 8 \\
\hline Milk, meat & 18 & 0 & 0 & 0 & 0 & 48 & 0 & 18 & 0 & 0 \\
\hline Total 2005-2010 & 2764 & 932 & 33.7 & 85 & 3.1 & & & 729 & 809 & 1226 \\
\hline
\end{tabular}

Notes. * - term "Fruits" includes fruits, berries fresh, frozen and dried and nuts; ** - term "Vegetables" - vegetables fresh and frozen, beans, peas, mushrooms, oil plants, infusions, tea and spices; *** - term "Others" - baby and infant food, juice and other processed foods; **** - samples origin "Dom" means domestic (Lithuanian) products, "EU" - products from EU countries, "Third" - products imported from third (non EU) countries. MRL - maximum residue level.

Residues at or below the MRL were found most often in oranges, mandarins, grapes/raisins, pomegranates, peaches, bananas, pears, strawberries and tea. Residues above the MRL were determined in the samples of fruits: grapes/raisins, oranges, lemons, other citrus, plums, pears, apples; in the samples of vegetables: peppers tomatoes, cucumbers, carrots, aubergines, cauliflowers. High exceedances of MRLs were determined in 5 samples of tea from China. More detailed information on samples with pesticide residues exceeding the MRL is presented in Table 3. Exceedances of MRLs in these products were found in other EU countries too. Additionally, exceedances of MRLs were determined in wild fungi from China, melons, beans, spices, okra, spinach, lettuce. The monitoring results presented in the USA reports show high level of pesticide residues in pears, grapes/ raisins, citrus fruit, peppers, cucumbers, tomatoes, carrots - similar to the results obtained by Lithuania researchers. Moreover, high level of pesticide residues was determined in imported blackberries, strawberries and other berries as well as mangoes, papaya, pepinos, bitter melon, peas, beans, eggplant, spinach and other vegetables (Pesticide Monitoring Program..., 2006; 2007; 2008). Apples, papayas, sweet peppers and strawberries were among products with the highest percentage of samples with residues above the MRL found in Brazilian pesticide residues monitoring programme (Jardim, Caldas, 2012). The commodities with the highest level of pesticide residues found in China were cabbage, legumes and leaf mustard (Chen et al., 2011).

Table 3. Samples with pesticide residues exceeding the maximum residue levels (MRLs) (2001-2010)

\begin{tabular}{ccccc}
\hline $\begin{array}{c}\text { Sampling } \\
\text { year }\end{array}$ & Commodity & $\begin{array}{c}\text { Samples } \\
\text { found/analysed }\end{array}$ & Country of origin & Pesticide residue \\
\hline 1 & 2 & 3 & 4 & Poland \\
\hline \multirow{2}{*}{2001} & apples & $1 / 27$ & Turkey & acephate \\
& raisins & $1 / 5$ & Spain & endosulfan \\
& peppers & $1 / 7$ & The Netherlands & endosulfan \\
\hline \multirow{2}{*}{2002} & cucumbers & $1 / 3$ & Morocco, Greece & chlorpyrifos, parathion-methyl \\
& mandarins & $2 / 15$ & dicofol & endosulfan \\
& plums & $1 / 5$ & Spain & dicofol
\end{tabular}


Table 3 continued

\begin{tabular}{|c|c|c|c|c|}
\hline 1 & 2 & 3 & 4 & 5 \\
\hline \multirow{5}{*}{2003} & grapefruit & $2 / 8$ & Turkey & chlorpyrifos \\
\hline & oranges & $1 / 18$ & Morocco & chlorpyrifos \\
\hline & peppers & $4 / 70$ & Spain & endosulfan \\
\hline & carrots (dried) & $1 / 10$ & Austria & 4,4'-DDE \\
\hline & tea & $5 / 24$ & China & fenvalerate \\
\hline \multirow{4}{*}{2004} & lemons & $2 / 6$ & Turkey & bromopropylate \\
\hline & plums & $1 / 2$ & Unknown & phosalone \\
\hline & raisins & $2 / 28$ & Iran & fenvalerate \\
\hline & tomatoes & $3 / 37$ & Lithuania & vinclozolin \\
\hline \multirow{4}{*}{2005} & lemons & $1 / 8$ & Turkey & parathion-methyl \\
\hline & apples & $1 / 24$ & Poland & dimethoate \\
\hline & raisins & $4 / 32$ & Iran & fenvalerate \\
\hline & tomatoes & $1 / 30$ & Lithuania & vinclozolin \\
\hline \multirow{10}{*}{2006} & grapes & $1 / 18$ & Turkey & imazalil \\
\hline & cauliflower & $1 / 11$ & Lithuania & dithiocarbamates \\
\hline & tomatoes & $1 / 22$ & Spain & endosulfan \\
\hline & apples & $1 / 25$ & Lithuania & dimethoate \\
\hline & pappers & $1 / 14$ & Spain & amitraz \\
\hline & plums & $1 / 6$ & France & chlorothalonil \\
\hline & wheat & $1 / 13$ & Lithuania & tebuconazole \\
\hline & raisins & $1 / 9$ & Iran & fenvalerate \\
\hline & orange & $1 / 14$ & Egypt & profenofos \\
\hline & lemon & $1 / 14$ & Turkey & parathion \\
\hline \multirow{13}{*}{2007} & peaches & $5 / 22$ & Spain & $\begin{array}{l}\text { carbendazim, azinphos-methyl, triadimefon, } \\
\text { dichlorvos, captan }\end{array}$ \\
\hline & apples & $1 / 18$ & France & carbendazim \\
\hline & strawberries & $2 / 24$ & Poland & endosulfan, carbaril \\
\hline & carrots & $1 / 15$ & Lithuania & diazinon \\
\hline & pomegranate & $3 / 7$ & Egypt & lambda-cyhalothrin, ethion \\
\hline & cucumbers & $1 / 16$ & Lithuania & endosulfam \\
\hline & oranges & $2 / 29$ & Egypt & formathion, fenitrothion \\
\hline & plums & $3 / 8$ & Hungary (2), Germany & binapacryl, flutriafol, carbaryl \\
\hline & tomatoes & $1 / 24$ & Spain & carbendazim \\
\hline & head cabbage & $1 / 17$ & The Netherlands & carbendazim \\
\hline & pears & $1 / 9$ & The Netherlands & carbaryl \\
\hline & bananas & $1 / 15$ & Equador & carbaryl \\
\hline & tea & $1 / 11$ & Egypt & bromoxynil \\
\hline \multirow{8}{*}{2008} & oranges & $3 / 12$ & Egypt, Spain, Morocco & diazonone, dimethoate, boscalid \\
\hline & pears & $2 / 13$ & The Netherlands, Spain & chlorpyrifos, demeton-S-methyl \\
\hline & pomegranates & $2 / 5$ & Egypt & ethion \\
\hline & cucumbers & $2 / 17$ & Lithuania & demeton-S-methyl, vinclozolin \\
\hline & tomatoes & $1 / 15$ & Lithuania & vinclozolin \\
\hline & bean & $1 / 2$ & Poland & demeton-S-methyl \\
\hline & tea & $2 / 8$ & China & buprofezin, thiazophos \\
\hline & wheat & $1 / 17$ & Lithuania & flucitrinate \\
\hline \multirow{8}{*}{2009} & pomegranate & $5 / 7$ & Turkey (2), Israel (2), Egypt & $\begin{array}{l}\text { acetamiprid, carbendazim, ethion, } \\
\text { lambda-cyhalothrin thiacloprid }\end{array}$ \\
\hline & grapes & $3 / 31$ & Turkey, Italy, USA & imazalil, chlorpyrifos-methyl, tecnazene \\
\hline & peppers & $1 / 16$ & Poland & thiophanate-methyl \\
\hline & aubergines & $2 / 15$ & Poland, The Netherlands & oxamyl \\
\hline & peas & $1 / 17$ & Belgium & azoxystrobin \\
\hline & tomatoes & $1 / 8$ & Poland & carbendazim \\
\hline & lettuce & $1 / 2$ & The Netherlands & dimethoate \\
\hline & rice & $1 / 11$ & Vietnam & acetamiprid \\
\hline \multirow{5}{*}{2010} & grapes/raisins & $8 / 34$ & $\begin{array}{c}\text { Egypt (2), Iran (2), } \\
\text { Macedonia (3), Turkey }\end{array}$ & $\begin{array}{l}\text { dimethoate, chlormequat, procymidone, } \\
\text { methomyl, thiodicarb }\end{array}$ \\
\hline & pomegranate & $2 / 8$ & Egypt, Turkey & carbendazim \\
\hline & oranges & $4 / 32$ & Egypt & fenitrothion, dimethoate, diazinon \\
\hline & tea & $1 / 3$ & India & acetamiprid, monocrotofos \\
\hline & baby food & $1 / 11$ & Slovenia & piperonyl butoxide \\
\hline
\end{tabular}

Many commodities contained more than one residue per product, up to 9 residues in grapes and tea were determined, up to 5-9 residues in citrus fruits orange, mandarins, lemons, peaches, pears and up 3-5 residues in pomegranates, plums, cucumbers, tomatoes, strawberries. The most frequently detected pesticide residues were imazalil, thiabendazole, chlorpyrifos, maneb group, procymidone, methidathion, lambda-cyhalothrin, carbendazim, iprodione, orthophenylphenol, vinclozolin, endosulfan, pyrimethanil, fenhexamid, prochloraz, cyprodinil, boscalid. The reason of high detection frequency of thiabendazole, imazalil residues is that these pesticides 
are widely used for post-harvest treatment of citrus fruits and bananas in order to preserve fruit during the transport process which may take several weeks. Residues of these pesticides were found in $70 \%$ of the imported citrus fruits and bananas at or below the MRL.

\section{Conclusions}

1. A high level of organochlorine pesticide contamination in meat and fish was determined in Lithuania during the period 1970-1976. Contamination gradually decreased after the most dangerous pesticides had been banned.

2. The level of contamination in milk and dairy products was lower, compared with that of meat and fish during the 1970-1976 period.

3 . The residues at or below the maximum residue level (MRL) in food of animal origin were found in 10 $20 \%$ of the samples analysed, exceedance of MRL has not been determined during the last 12 years in Lithuania.

4. Percentage of samples with residues at or below the MRL in food of plant origin ranged from $20 \%$ to $60 \%$ of the samples analysed, exceedances of MRLs ranged from $1.5 \%$ to $4.6 \%$.

5. Grapes/raisins, oranges, pomegranates and tea imported from third countries, were commodities in which pesticide residues were most often determined. Most of these matrixes contained more than one pesticide residues.

6. Contamination of domestic products was not high, pesticide residues exceedances of MRLs were determined in 13 samples out of 1240: apples, cucumbers, tomatoes, cauliflower, carrots and wheat.

7. Imazalil, thiabendazole, chlorpyrifos, maneb group, procymidone, methidathion, lambda-cyhalothrin, carbendazim, iprodione, orthophenylphenol, vinclozolin, endosulfan, pyrimethanil, fenhexamid, prochloraz, cyprodinil, boscalid were the pesticides whose residues were most frequently detected.

Received 19062012

Accepted 11122012

\section{References}

2007 Annual Report on Pesticide Residues according to Article 32 of Regulation (EC) No 396/2005. EFSA Scientific Report, 2009, p. 46-52. <http://www.efsa.europa.eu/en/ efsajournal/pub/305r.htm $>$ [accessed 0606 2012]

2008 Annual Report on Pesticide Residues according to Article 32 of Regulation (EC) No 396/2005. EFSA Journal, 2010, 8 (7): 1646, p. 62-76. <http://www.efsa.europa.eu/en/ efsajournal/pub/1646.htm $>$ [accessed 0606 2012]

Chen C., Qian Y., Chen Q., Tao C., Li C., Li Y. 2011. Evaluation of pesticide residues in fruits and vegetables from Xiamen, China. Food Control, 22 (7): 1114-1120 http://dx.doi.org/10.1016/j.foodcont.2011.01.007

DDT Factsheet. 1998. Pesticide Action Network UK. <http:// www.pan-uk.org/pestnews/Actives/ddt.htm $>$ [accessed 0204 2012]

Golubevas R., Radžiūtė E., Vaičiūnas V., Petraitis J., Jarmalaite I. 2012. Monitoring of pesticide residues in 2010 $7^{\text {th }}$ Baltic Conference on Food Science and Technology FOODBALT-2012. Kaunas, Lithuania, p. 186-187
Hjorth K., Johansen K., Holen B., Andersson A., Christensen H. B., Siivinen K., Toome M. 2011. Pesticide residues in fruits and vegetables from South America: a Nordic project. Food Control, 22 (11): 1701-1706 http://dx.doi.org/10.1016/j.foodcont.2010.05.017

Jardim A. N. O., Caldas E. D. 2012. Brazilian monitoring programs for pesticide residues in food - results from 2001 to 2010. Food Control, 25 (2): 607-616 http://dx.doi.org/10.1016/j.foodcont.2011.11.001

Jarmalaitè I., Jurkaitė A., Petraitis J., Vaičiūnas V., Vareikaitè R., Viščiulytė V. 2003. Pesticide residues in food of plant origin in year 2002: Conference of Food Chemistry and Technology. Kaunas, Lithuania, p. 42-44 (in Lithuanian)

Molina C., Falcon M., Barba A., Camara M. A., Oliva J., Luna A. 2005. HCH and DDT residues in human fat in the population of Murcia (Spain). Annals of Agricultural and Environmental Medicine, 12 (1): 133-136

Monitoring of pesticide residues in products of plant origin in the European Union, Norway, Iceland and Liechtenstein, 2002 Report. 2004. <http://ec.europa.eu/food/fvo/ specialreports/pesticide_residues/report_2002_en.pdf $>$ [accessed 1405 2012]

Monitoring of pesticide residues in products of plant origin in the European Union, Norway, Iceland and Liechtenstein, 2003 Report. 2005. <http://ec.europa.eu/food/fvo/ specialreports/pesticide residues/report 2003 en.pdf $>$ [accessed 1505 2012]

Monitoring of pesticide residues in products of plant origin in the European Union, Norway, Iceland and Liechtenstein, 2004 Report. 2006. <http://ec.europa.eu/ food/fvo/specialreports/pesticide_residues/report_2004 en.pdf $>$ [accessed 1805 2012]

Monitoring of pesticide residues in products of plant origin in the European Union, Norway, Iceland and Liechtenstein, 2005 Report. 2007. <http://ec.europa.eu/food/fvo/ specialreports/pesticide_residues/report_2005_en.pdf $>$ [accessed 2205 2012]

Monitoring of pesticide residues in products of plant origin in the European Union, Norway, Iceland and Liechtenstein, 2006 Report. 2008. <http://ec.europa.eu/food/fvo/ specialreports/pesticide_residues/report_2006_en.pdf $>$ [accessed 2205 2012]

Pesticide Monitoring Program PESTICIDE 2006. Results and discussion.U.S.FoodandDrugAdministration. $<$ http://www. fda.gov/Food/FoodSafety/FoodContaminantsAdulteration/ Pesticides/ResidueMonitoringReports/ucm125187.htm> [accessed 0304 2012]

Pesticide Monitoring Program PESTICIDE 2007. Results and discussion.U.S.FoodandDrugAdministration. $<$ http://www. fda.gov/Food/FoodSafety/FoodContaminantsAdulteration/ Pesticides/ResidueMonitoringReports/ucm169577.htm> [accessed 0304 2012]

Pesticide Monitoring Program PESTICIDE 2008. Results and discussion.U.S.FoodandDrugAdministration. $<$ http://www. fda.gov/Food/FoodSafety/FoodContaminantsAdulteration/ Pesticides/ResidueMonitoringReports/ucm228867.htm> [accessed 0304 2012]

Pesticide Residues in Food 1996. DDT (021). Report Sponsored Jointly by FAO and WHO. Rome, Italy, p. 151-165. $<$ http://www.fao.org/ag/AGP/AGPP/Pesticid/JMPR/ Download/96_eva/ddt.pdf $>$ [accessed 2311 2012]

Petraitis J., Pockevičiūtè A., Uščinas R., Kuliešienė D., Vaičiūnas V. 2001. Determination of pesticide residues during period of 1970-2000: Conference of Food Chemistry and Technology. Kaunas, Lithuania, p. 122-125 (in Lithuanian) 
Petraitis J., Vareikaitė R., Vaičiūnas V., Jarmalaitė I. 2007. Pesticide residues in food of plant origin: $2^{\text {nd }}$ Baltic conference on food science and technology FOODBALT-2007. Kaunas, Lithuania, p. 50

Petraitis J., Jarmalaitè I., Vaičiūnas V., Golubevas R. 2009. Pesticide residues monitoring in food of plant origin: $4^{\text {th }}$ Baltic conference on food science and technology FOODBALT-2009. Kaunas, Lithuania, p. 22

Petraitis J., Jarmalaite I., Vaičiūnas V. 2011. Forty years of monitoring of pesticide residues in Lithuania: $10^{\text {th }}$ international conference of Lithuanian chemists CHEMISTRY 2011. Vilnius, Lithuania, p. 85
Scientific Report of EFSA 2011. The 2009 European Union Report on Pesticide Residues in Food. EFSA Journal, 9 (11): 2430

Uščinas R., Pockevičiūtè A., Baranauskas A., Plaušinaitis R., Kranauskas A. 1999. Determination of chloroorganic pesticides in human fat tissues: conference of food chemistry and technology. Kaunas, Lithuania, p. 100-103 (in Lithuanian)

Vaičiūnas V., Golubevas R., Petraitis J., Jarmalaitė I. 2011. Monitoring of pesticide residues in 2009: $10^{\text {th }}$ international conference of Lithuanian chemists CHEMISTRY - 2011. Vilnius, Lithuania, p. 116

ISSN 1392-3196 / e-ISSN 2335-8947

Zemdirbyste-Agriculture, vol. 100, No. 2 (2013), p. 205-212

DOI $10.13080 /$ z-a.2013.100.027

\title{
Pesticidų likučių maisto produktuose tyrimų Lietuvoje apžvalga
}

\author{
J. Petraitis ${ }^{1}$, I. Jarmalaité1, V. Vaičiūnas ${ }^{1}$, R. Uščinas² ${ }^{2}$ G. Jankovskienė ${ }^{3}$ \\ ${ }^{1}$ Nacionalinis maisto ir veterinarijos rizikos vertinimo institutas \\ ${ }^{2} \mathrm{UAB}$,Labtarna““ \\ ${ }^{3}$ Nacionalinè visuomenès sveikatos priežiūros laboratorija
}

\section{Santrauka}

Straipsnyje pateikta pesticidų tyrimų Lietuvoje raida nuo 1970 iki 2010 m. Pirmuoju laikotarpiu iki 1993 m. tyrimai buvo atliekami pavienių pesticidų likučių nustatymo metodais. Dauguma produktų buvo vietinès kilmės ir žinota, kokie pesticidai naudoti, todèl, taikant paprastus ir pigius pavienių pesticidų likučių nustatymo metodus, buvo galima ištirti dideli kieki mėginių. Lietuvoje pesticidų likučius tyrè penkios laboratorijos, kurios per metus ištirdavo po 3-5 tūkstančius mėginių. Pirmaisiais metais nustatyta didelis gyvūninès kilmès produktų užterštumas pesticidų likučiais. 1972 m. dalis mèsos ir žuvų produktų, kuriuose pesticidų likučių koncentracija viršijo didžiausią leidžiamą kiekį, sudare net 8,1 \%. Vèliau šis užterštumas smarkiai mažèjo, ir gyvūninès kilmès produktų tarša nebekèlè didesnių problemų. Augalinės kilmès maisto užterštumas labai nekito ir sudare $1-3 \%$.

Žymiai padidejus importui ir trūkstant informacijos apie naudotus pesticidus, pavieniais pesticidu likučiu nustatymo metodais jau nebebuvo galima užtikrinti efektyvios taršos kontrolès, todèl buvo diegiami ir tobulinami daugiapakopiai pesticidų likučių nustatymo metodai. Šie metodai viename mėginyje leidžia nustatyti iki 300 pesticidų likučių. Buvo ištirti 4593 augalinès kilmės mėginiai, pesticidų likučių nustatyta 1428 mėginiuose (31\%). Didžiausios leidžiamos koncentracijos viršijimas nustatytas 120 mėginių $(2,6 \%)$.

Reikšminiai žodžiai: daugiapakopis pesticidų likučių nustatymo metodas, maistas, pavienių pesticidų likučių nustatymo metodas, pesticidai, pesticidų likučiai. 